\title{
The Development of Antimicrobial and Food Preservative Agents from the Combination of Emprit Ginger (Zingiber officinale var. amarum) and Nisin
}

\author{
D A Ashari ${ }^{1}$, R Utami $^{1,2}$, A M Sari $^{1}$, A Nursiwi $^{1}$, and A Nissa ${ }^{1}$ \\ ${ }^{I}$ Department of Food Science Technology, Sebelas Maret University, Jl. Ir Sutami 36A, Kentingan, Jebres, \\ Surakarta, 57126, Indonesia \\ ${ }^{2}$ Corresponding author: rohulautami@staff.uns.ac.id
}

\begin{abstract}
Salmonella typhimurium, Eschericia coli, Pseudomonas fluorescense, and Aspergillus niger are common contaminants in food. Microbial contamination in food may lead to food spoilage and foodborne diseases. The development of new antimicrobial agent, especially from natural resources is needed to prevent microbial contamination. In this study, $0.0625,0.125,0.25,0.5,1,2 \%(\mathrm{v} / \mathrm{v})$ ginger (Zingiber officinale var. amarum) essential oil (EO) was combined with $62.5,125,250,500,1000$, and 2000 IU of nisin to inhibit the growth of S. typhimurium, E. coli, P. fluorescens, and A. niger. Microdilution method was used to identify the Minimum Inhibitory Concentration (MIC) of that combination. Combination of $62.5 \mathrm{IU}$ and $0.125 \%$ could inhibit the growth of A. niger, $62.5 \mathrm{IU}$ and $1 \%$ EO inhibited the growth of E. coli and Pseudomonas fluorescens, and 62.5 IU added with $2 \%$ EO was able to inhibit the growth of $S$. typhimurium. The effect of combination was analysed by comparing the concentration of nisin or EO needed to inhibit the growth of microorganism with the concentration of combinated nisin and EO. The combination showed indiffence effect on Bacillus cereus, on Aspergillus niger it showed partial synergist effect, and on Salmonella typhimurium, Staphylococcus aureus, Pseudomonas fluorescens, Eschericia coli it produced antagonistic effect. The use of nisin, ginger EO, and the combination of ginger and nisin can be used as one of the alternative of antimicrobial agent and food preservative agent since it can inhibit the growth of food spoilage microorganisms and foodborne pathogen.
\end{abstract}

Keywords: Antimicrobial, Emprit Ginger, Nisin.

\section{INTRODUCTION}

Food is essential for human life, it provides nutritions for human body. Unfortunately, it is easily damaged, one of them is caused by microorganisms. Data from BPOM between 20142017, showed that most foodborne diseases in Indonesia were caused by microbial contaminations $[1,2,3,4]$. It illustrates that the contamination of microorganisms will cause not only food spoilage but also foodborne diseases. For that reason, we need to develop a new way to prevent contamination on food.

Nowadays, consumers want their food contains less synthetic materials (including preservative agents) and minimally processed. Natural preservative agents is one of the option that we can develop. Natural agents, such as essential oil, bacteriocin, oleoresin and others were potentially to be developed, because of their activities, including its antimicrobial activities. 
Essential oils are the secondary metabolites of plants, it is volatile and aromatic. Several activities including antibacterial, antiparasitic, insectisidal, antiviral, antifungal, and atioxidant activities were showed by the essential oils [5]. Zingiber officinale var. amarum or usually called as "jahe emprit" was generally used by Indonesian, it was also highly produced. In 2017, the production of ginger in Indonesia reached 216 tonnes [6]. Besides, ginger also showed antimicrobial activities, ginger rhizomes essential oil showed inhibition activity on Listeria monocytogenes, Staphylococcus aureus, Bacillus subtilis, Eschericia coli, and others [7]. But, higher use of essential oil in food products influences its sensory value [8].

Bacteriocins are peptides which ribosomally synthesized by bacteria, it shows bacteriostatic or

\section{MATERIAL AND METHOD}

\subsection{Essential oil preparation}

Ginger (Zingiber officinale var. amarum) was obtained from Pasar Legi, Surakarta, Indonesia. The soil was removed from the ginger after sortation. Clean and good quality ginger was sliced with thickness between 2 and $3 \mathrm{~mm}$. Then, it was dried under the air-drying condition for 4-6 days. The moisture content of the simplicia was tested, and after it reached 15-16\%, it was distillated. Stahl apparatus was used to obtain the essential oil [10]. GC-MS Shimadzu QP 2010 (Tokyo, Japan) was used for analysing the chemical components of ginger essential oil. One $\mu \mathrm{l}$ of EO was injected into the instrument which had injection temperature of $300^{\circ} \mathrm{C}$. The temperature of the oven was setted on $50^{\circ} \mathrm{C}$ then it increased $5^{\circ} \mathrm{C} /$ minute until $240^{\circ} \mathrm{C}$ as the final temperature. Helium was used as carrier gas with flow rate on $0.55 \mathrm{ml} /$ minute and the pressure on $14.0 \mathrm{kPa}$ [11].

\subsection{Inoculum preparation}

Bacillus cereus FNCC 0057, Salmonella typhimurium FNCC 0050, Staphylococcus aureus FNCC 0047, Eschericia coli FNCC 0091, Pseudomonas fluorescens FNCC 0070, and Aspergillus niger FNCC 6080 were used. All of the inoculum stocks were refreshed, the bacteria were growth on Nutrient Agar (NA) for 24 hours while the fungi culture was growth on Potato Dextrose Agar (PDA) for 3 days. The inoculum was suspended into saline water and adjusted with 0.5 McFarland [12]. The microorganism stock cultures were obtained from Pusat Studi Pangan dan Gizi, Gadjah Mada University, Indonesia. bactiricidal activity against other microorganism. Nisin as one of the example of bacteriocin is produced by Lactococcus lactis subs. lactis. It is effectively inhibited the growth of several Gram positive bacteria including Lactococcus, Streptococcus, Staphylococcus, and so on but less effective on Gram negative bacteria, fungi, and virus [9].

The combination of ginger, Zingiber officinale var. amarum, essential oil and nisin may enhance the effectivity of the EO and/or nisin. This study was done to observe the effect of the combination between Zingiber officinale var. amarum and nisin against several microorganisms such as Bacillus cereus, Salmonella typhimurium, Staphylococcus aureus, Eschericia coli, Pseudomonas fluorescens, and Aspergillus niger.

\subsection{Minimum Inhibitory Concentration (MIC) test}

MIC value was observed by using microdilution method $[12,13]$. Nisin $\left(10^{6} \mathrm{IU}\right)$ was diluted in $10 \mathrm{ml}$ of Mueller Hinton Broth or RPMI $16402 \%$ of glucose without bicarbonate until it reached 2000, 1000, 500, 250, 125 and 62.5 IU. Essential oil dilution was made by using the same method. 2, 1, $0.5,0.25,0.125$ and $0.0625 \%(\mathrm{v} / \mathrm{v})$ of ginger essential oil dilutions were made. $0.5 \%(\mathrm{v} / \mathrm{v})$ of Tween 20 was added to the solution to make the dilution becomes more stable.

Both solutions were pippetted in to the 96-wells microplate. Each wells were filled with $50 \mu$ of each nisin solutions and ginger essential oil solutions, then $10 \mu \mathrm{l}$ of bacteria suspension and incubated for 20 hours. Another plate were added with $100 \mu \mathrm{l}$ of fungi suspension and incubated for 48 hours. The minimum concentration that could inhibit the growth of the microorganisms were the $\mathrm{MIC}$ value.

\subsection{Synergism Effect Analysis}

MIC values of each agent were used for counting the Fractional Inhibitory Concentration (FIC) index to analyse the synergism effect. The FIC index was counted by adding the concentration needed by agent $\mathrm{A}$ in single used mode per the concentration in combined mode with the concentration needed by agent $B$ in single used mode per concentration in combined mode.

FIC Index $=$ FICA + FICB 


$$
\mathrm{FIC} B=\frac{\mathrm{B}}{\mathrm{NICB}}
$$

FIC $<0.5$ shows synergistic effect, $0.5<$ FIC $<$ 0.76 determines partial synergistic effect. Additive effect is determined with $0.76<$ FIC $<1,1<$ FIC $\leq 4$

\section{RESULT AND DISCUSSION}

\subsection{Chemical Components of Ginger (Zingiber officinale var. amarum) Essential Oil}

Ginger essential oil consist of several chemical components (Table 3.1). Z-citral (24.85\%) was the denotes indifference effect, and antagonistic effect is identified when FIC > 4 [14].

biggest component on ginger essential oil, followed by citral (19.99\%), camphene (15.35\%), 1,8 cineole $(8.74 \%)$, and so on.

Table 1. Chemical Composition of Ginger EO.

\begin{tabular}{ll}
\hline Ginger Essential Oil & Percentage (\%) \\
\hline Z-citral & 24.85 \\
Citral & 19.99 \\
Camphene & 15.35 \\
1,8 cineole & 8.74 \\
Ar-curcumene & 2.91 \\
Alpha-pinene & 2.84 \\
Geranyl acetate & 2.48 \\
Zingiberene & 2.46 \\
Myrcene & 2.06 \\
Beta-sesquiphellandrene & 1.70 \\
Linalool & 1.54 \\
\hline
\end{tabular}

There was a different on the chemical component forming ginger essential oil with the previous studies. Nigerian fresh ginger oil contained beta zingiberene (12.2\%), 1,8 cineole+limonene+beta phellandrene (10.5\%), geraniol $(15 \%)$, and so on. While, dried rhizome consisted from beta zingiberene (28.1\%), 1.8 cineole+limonene+beta phellandrene (4.5\%), geraniol $(9.0 \%)$ and so on. Those variations were affected by the source of rhizome, freshness, and distillation methods [7].

\subsection{Minimum Inhibitory Concentration (MIC) and} FIC index

On this study, the MICs were shown on Table 2. The use of nisin and ginger (Zingiber officinale var. amarum) essential oil showed some different responses among microorganisms tested. Nisin was active against Bacillus cereus (2000 IU), Eschericia coli (500 IU), Pseudomonas fluorescens (500 IU), and Aspergillus niger (250 IU). While, ginger essential oil was active on all microorganisms tested (as shown on the Table 2), further, lower concentration of EO $(<0.0625 \%)$ were needed to inhibit the growth of Bacillus cereus and Staphylococcus aureus. 
Table 2. The MIC of Nisin, Ginger Essential Oil, Their Combination, and Their Synergism Effect.

\begin{tabular}{|c|c|c|c|c|c|}
\hline \multirow[b]{2}{*}{ Microorganism } & \multicolumn{3}{|c|}{ Minimum Inhibitory Concentration } & \multirow[b]{2}{*}{ FIC } & \multirow{2}{*}{$\begin{array}{c}\text { Synergism } \\
\text { effect }\end{array}$} \\
\hline & $\begin{array}{c}\text { Nisin } \\
(\mathrm{IU})\end{array}$ & $\begin{array}{c}\text { Essential } \\
\text { oil }(\%)\end{array}$ & $\begin{array}{c}\text { Nisin (IU) }+ \\
\text { Essential Oil (\%) } \\
\end{array}$ & & \\
\hline Bacillus cereus FNCC 0057 & 2000 & $<0.0625$ & $62.5+0.125$ & 2,034 & I \\
\hline $\begin{array}{l}\text { Salmonella typhimurium } \\
\text { FNCC } 0050\end{array}$ & $>2000$ & 0.5 & $62.5+2$ & 4,031 & A \\
\hline $\begin{array}{l}\text { Staphylococcus aureus FNCC } \\
0047\end{array}$ & $>2000$ & $<0.0625$ & $62.5+2$ & 32.082 & A \\
\hline Eschericia coli FNCC 0091 & 500 & 0.0625 & $62.5+1$ & 16.125 & A \\
\hline $\begin{array}{l}\text { Pseudomonas fluorescens } \\
\text { FNCC } 0070\end{array}$ & 500 & 0.25 & $62.5+1$ & 4.125 & A \\
\hline Aspergillus niger FNCC 6080 & 250 & 0.25 & $62.5+0.125$ & 0.75 & $\mathrm{P}$ \\
\hline
\end{tabular}

P : Partial synergistic effect

I : Indifference effect

Both antimicrobial agents used in this study had antimicrobial activity by binding the lipid II of the microorganism. This mechanism will destroyed the membrane cell of the microorganisms, and caused lysis $[15,16]$. From the data, it is revealed that the combination of nisin and ginger essential oil could decrease the use of nisin but it increased the use of essential oil, except for Aspergillus niger. To inhibit the growth of Bacillus cereus FNCC 0057, Salmonella typhimurium FNCC 0050, Staphylococcus aureus FNCC 0047, Eschericia coli FNCC 0091, and Pseudomonas fluorescens FNCC 0070 , the combination of $62.5 \mathrm{IU}+0.125 \%, 62.5$ $\mathrm{IU}+2 \%, 62.5 \mathrm{IU}+2 \%, 62.5 \mathrm{IU}+1 \%$, and $62.5 \mathrm{IU}+1 \%$ of nisin and ginger essential oil were needed respectively. On Bacillus cereus, the combination showed indifference effect, whilst on the four other bacterias it showed antagonistic effect. Those effect might be caused by the reduction of essential oil's activity, nisin might prevent the work of the essential oil and vice versa. On the previous research, the use of nisin and oregano essential oil on the same time also showed antagonistic effect [17].

While on the Aspergillus niger, the combination between nisin and ginger essential oil increased the activity of both agents. The spesific antifungal mechanism of the combination were not well understand yet. On the previous research, the use of turmeric essential oil could inhibit the growth of Aspergillus flavus [18]. The use of essential oil reduced the number of ergosterol, which is the major sterol component of the fungal cell membrane [19].
A : Antagonistic effect

\section{CONCLUSION}

The combination between nisin and ginger (Zingiber officinale var. amarum) essential oil increased the activity of both agents when it used on Aspergillus niger. Combination of $62.5 \mathrm{IU}$ of nisin and $0.125 \%$ of ginger essential oil could inhibit the growth of Aspergillus niger. While, on the other microorganisms, the combination was resulting indifference and antagonistic effect.

\section{ACKNOWLEDGMENT}

This work was financially supported by research project of PNBP UNS 623/UN27.21/PP/2017. The authors fully acknowledged Sebelas Maret University for the approved fund which makes this important research viable and effective.

\section{REFERENCES}

[1] BPOM 2015 Laporan Tahunan Tahun 2014 Badan Pengawas Obat dan Makanan (Jakarta: Badan Pengawas Obat dan Makanan)

[2] BPOM 2016 Laporan Tahunan Tahun 2015 Badan Pengawas Obat dan Makanan (Jakarta: Badan Pengawas Obat dan Makanan)

[3] BPOM 2017 Laporan Tahunan Tahun 2016 Badan Pengawas Obat dan Makanan (Jakarta: Badan Pengawas Obat dan Makanan)

[4] BPOM 2018 Laporan Tahunan Tahun 2017 Badan Pengawas Obat dan Makanan (Jakarta: Badan Pengawas Obat dan Makanan)

[5] Hyldgaard M, Mygind T, and Meyer R L 2012 Frontiers in Microbiology 3(12) 1-24. 
[6] BPS 2018 Statistik Tanaman Biofarmaka Statistics of Medicinal Plants Indonesia (Jakarta: Badan Pusat Statistik)

[7] Mahboubi M 2019 Clinical Phytoscience 5(6) $1-12$

[8] Dwijatmoko M I, Praseptiangga D, and Muhammad D R 2016 Nusantara Bioscience 8(2) 301-305

[9] Arauz, L J, Jozala A F, Mazzola P G, and Penna T C 2009 Trends in Food Science \& Technology 20(2009) 146-154

[10] Sadgrove N and Jones G 2015 Agriculture 5 48-102

[11] Jayanudin 2011 Jurnal Teknik Kimia Indonesia 10(1) 37-42

[12] CLSI 2012 Methods for Dilution Antimicrobial Susceptibility Tests for Bacteria that Grow Aerobically; Approved Standard-Ninth Edition (Pennsylvania: Clinical and Laboratory Standards Institute)

[13] ESCMID 2015 EUCAST Definitive Document E.Def 9.3 Method for the Determination of Broth Dilution Minimum Inhibitory Concentrations of Antifungal Agents for Conidia Forming Moulds (Copenhagen: European Society of Clinical Microbiology and Infectious Diseases)

[14] Sasidharan N K, Sreekala S R, Jacob J and Nambisan B 2014 Biomed Research International 2014 1-8

[15] Jozala A F, Novaes L C and Junior A P 2015 Nisin (Croatia: Intech)

[16] O'Bryan C A, Pendleton S J, Crandall P G and Ricke S C 2015 Frontiers in Veterinary Science 2(35) 1-8

[17] Silva J P, Souza E F, Modesta R C, Gomes I A, Freitas-Silva O and Franco B D 2015 Artigo 4(1) 83-91

[18] Hu Y, Zhang J, Kong W, Zhao G and Yang M 2017 Food Chemistry 220 1-8

[19] Pinto E, Vale-Silva L, Cavaleiro C and Salgueiro L 2009 Journal of Medical Microbiology 58 1454-1462 